\title{
Research on the Implementation Method of Multidimensional Interactive Teaching Method in College English Teaching
}

\author{
Shi Yingying \\ Hunan University of Arts and Science, Changde Hunan, 415000, China
}

\begin{abstract}
English teaching is to hope that students can make comprehensive use of it. Therefore, in order to enable students to achieve this goal, multi-dimensional interactive teaching methods are introduced to improve students' English learning ability.Under this teaching method, teachers should take students as the basis of teaching, sum up their experience constantly in English teaching, innovate and improve English teaching methods with the times, so that students' listening, speaking, reading and writing ability can be developed, and lay a good foundation for students' later life and study.This paper will describe the concept of multidimensional interactive teaching method, and point out the problems existing in college English teaching and the current situation of multi-dimensional interactive teaching method in college English teaching, and describe the perfect measures.
\end{abstract}

Keywords:English Teaching;Multi-dimensional Interactive Teaching Method; Colleges and Universities

English is a compulsory course for students. In English teaching, teachers need to cultivate students' English consciousness and English application ability. In the traditional English teaching mode, the "spoon-feeding" teaching method has caused serious consequences to English teaching, which greatly erases the enthusiasm and initiative of students and makes students in a passive learning. This traditional teaching method no longer meets the needs of college English teaching in the present era, so it is necessary to introduce new teaching methods to teach students English.At this time, the multidimensional interaction method appeared in front of educators.

https://doi.org/10.47852/bonviewCETR2020010207

This is an open access article published by the BON VIEW PUBLISHING PTE. under the Creative Commons Attributions License. 


\section{Multidimensional Interactive Teaching}

Multi-dimensional interactive teaching method is a kind of multi-directional communication and communication between teachers and students, students and groups. This teaching method requires effective interaction between students and teachers in the classroom, friendly and harmonious coexistence between teachers and students. It is a dynamic teaching unity. By adopting multidimensional interactive teaching method in the classroom, teachers and students communicate with each other, so that the classroom can truly realize individualized learning, make the classroom teaching fully humanized, and then promote the students' learning ability to be improved.It can also promote students to study independently and cooperatively, make students develop good study habits, and play a great role in cultivating their comprehensive ability ${ }^{[1]}$.

\section{Problems in College English Teaching}

Nowadays, English teaching in colleges and universities is still deeply influenced by the concept of examination-oriented education. Students and teachers attach great importance to English learning results. After a long period of fermentation, students' judgment on themselves is out of balance, resulting in psychological problems. At the same time, in the educational reform, more attention is paid to the reform and innovation of teaching ideas and methods, and the corresponding attention and guidance should be paid to the students' learning psychological state and emotion. At the same time, in the actual English teaching class, the status of teachers is still higher than that of students, which leads to the students still in a passive learning state, which is not conducive to the students' English knowledge learning ${ }^{[2]}$.

The classroom atmosphere is very important in English teaching. A good classroom atmosphere can make students' learning effect multiply and promote their active learning. A pleasant and relaxed classroom atmosphere is also more conducive to students' divergent thinking. Promote their thinking ability and innovation ability to be improved.However, in the actual English classroom are extremely boring, students drowsy, can not afford to learn English knowledge, their enthusiasm and enthusiasm for English learning is gradually being worn away.In addition, there is little harmonious communication between teachers and students. The only communication is when the teacher asks English questions and the students answer them. This situation is not conducive to teachers understanding students' thoughts, unable to enter the group of students, and then will affect the quality and effect of teaching.

\section{Teaching Status of Multi-dimensional Interactive Teaching Method in College English Teaching}

First of all, according to the current situation of college English teaching, Chinese college English teaching pays more attention to teaching students' listening, reading and writing ability in English, and all of them complete English teaching tasks alone.However, the subject of English itself has the 
advantages of interactivity and communication. When teaching students English knowledge, teachers should also pay attention to the teaching of students' English speaking ability, promote English communication between students and students, teachers and students, and achieve multidimensional interaction in multidimensional interactive teaching method.This can also effectively improve students' English proficiency but low English practice ability ${ }^{[3]}$.

In addition, teachers and students, students and students are required to communicate and learn in multidimensional interactive teaching, so as to break the one-to-many teaching situation in traditional English teaching, but in actual English teaching, Teachers do not transform their teaching methods in time, still using traditional teaching methods. When multidimensional interactive teaching method enters English teaching, teachers habitually use traditional teaching methods to teach students English knowledge.This way will only make students still in a passive learning state, can not make good use of classroom time for English dialogue and communication, so that students only learn English answer skills, can not have skilled English communication skills.And in a classroom without communication and communication, students will naturally feel that the classroom is boring and boring, and eventually become bored, and the whole classroom is in a depressed atmosphere.

\section{Concrete Measures of Using Multi-dimensional Interactive Teaching Method in College English Teaching}

A. Changing Teaching Ideas

In order to make multi-dimensional interactive teaching method play its greatest advantage in English teaching, it is necessary for English teachers to change their teaching ideas in time and adopt new teaching methods to teach students English knowledge. This requires teachers not to judge students' English learning ability by their English test results, but to look at the whole of students from a comprehensive and developing perspective, and to judge students' English learning ability by the whole of students.In addition, in the process of teaching, teachers should also pay attention to their position in the classroom and their role in the classroom, abandon the image of teachers in the past, and enter the student group with approachable approach. Let students play their own main position, actively involved in English teaching.Teachers should also stimulate students' enthusiasm and initiative in English learning, promote the effective application of multi-dimensional interactive teaching methods in English classroom, and give play to their own advantages to guide students to actively explore English knowledge. Let them roam freely in the sea of English knowledge and promote their English learning ability $^{[4]}$.

B. Enrich students' English teaching activities

In English teaching, teachers actively carry out rich teaching activities for students, which is more conducive to increasing the diversity of interaction in the classroom, and creating better implementation conditions for multidimensional interactive teaching methods.In the implementation of multidimensional interactive teaching methods, teachers need to create as many English teaching activities as 
possible, so as to promote the formation and development of multi-dimensional interaction, strengthen the interaction of various groups in the classroom, thus breaking the one-to-many teaching mode in traditional teaching, breaking through the formal communication and communication in traditional teaching, so that students and students, teachers and teachers can have real and effective interactive communication, thus promoting students' English learning.Through all kinds of English teaching activities, teachers can observe each student in the activities, sum up the advantages and disadvantages of the students, and then sort out their own teaching courseware. Make more suitable courseware to promote students' English ability, so as to promote the development of students. Teachers should also actively participate in English teaching activities, communicate with students, share opinions or suggestions, enter students, listen to their inner voices, and then make corresponding changes to help students make better progress ${ }^{[5]}$.

For example, the teacher can organize group debate in English class, assign a topic through the teacher, let the students collect and organize the data in the group, and then arrange the debater, so that the positive and negative sides can debate in English on the topic specified by the teacher.The development of this debate competition can play a great role in the students' comprehensive use of English knowledge. Students can find-attacks by collecting information, organizing sentences and guessing the arguments that the other debater may throw out.Through this process, students can not only exercise their ability to use English syntactic structure, but also promote their ability to speak English.Of course, after the debate, the teacher can also reward the winning party to encourage and promote students to participate more actively in English knowledge learning.

C. Building Group Cooperative Learning

In college English classes, students get along for a long time. They know each other very well. Teachers can set up group cooperative learning according to this characteristic of students, so that students can interact and help each other in many dimensions. In order to improve their English learning ability.People of the same age and level can communicate with each other more easily. They can share topics and hobbies, which can promote friendly interaction between each other.Because of the influence of the traditional teaching method, the students dare not question or question the English knowledge taught by the teacher in the classroom, which has caused some restraint to the students' innovative ability and personality development.In multidimensional interactive teaching, students and students need to be able to communicate, give most of the time to students for autonomous learning and exploration, but also to teachers teach English knowledge for a reflection, To actively seek relevant information for verification. With the support and help of their friends, the middle school students in the group have the courage to question the English knowledge taught by the teacher. When the students dare to express their opinions, big step forward.The group cooperative learning model can make students think and discuss English problems more comprehensively and from many angles, promote the progress and growth together under the joint action of the group members, and then improve their English learning ability and promote their all-round development ${ }^{[6]}$. 
For example: in college English classes, teachers can let students live in groups of 4-6, and then teachers ask specific English questions. For example: what do you think of group cooperation learning in English teaching?Through this question, the members of the group are asked to collect, organize and summarize the information, and then the group members nominate one member to speak in English and express their views in their own group.In this, the teacher mainly wants to examine the students' English language expression ability, logical thinking and expression habits and their cooperation tacit understanding. In this way, in stimulating group cooperative learning, group members can also realize the importance of cooperation, and then promote cooperation and exchange among students.

\section{Acknowledgement}

This work is supported in part by Teaching Research Reform Project of Hunan Province in 2020: A Study on the Construction of the Mixed "Gold Course" in the Online and Offline Course of College English Public Speech(No.HNJG-2020-0745)

\section{Conclusion}

In a word, the introduction of multi-dimensional interactive teaching mode in college English teaching can promote the interactive communication between teachers and students, and promote their English learning ability in friendly communication.At the same time, in this mode, the teacher can also take the students as the foundation in the classroom to carry on the reasonable design of the teaching courseware, pay attention to the cultivation of the students' comprehensive English ability, so that the students can communicate and communicate effectively with the teachers and students in a relaxed and pleasant atmosphere.

\section{References}

[1] Liu Bin. Application of Multi-dimensional Interactive Teaching Model in College English Teaching [J].].1 Shenhua ,2018,(12):115-115.

[2] Zhou Yun. Discussion on the Application of Multi-dimensional Interactive Teaching Model in College English Teaching [J]. Intelligence ,2018(6):77-77.

[3] Xie Qiong. Discussion on the Application of Multi-dimensional Interactive Teaching Model in College English Teaching [J]. v.17;No.566(29):127,2019 129.

[4] Wang Wei. Application of Multi-dimensional Interactive Teaching Model in College English Teaching [J].]; and Publication ,2019,(21):134-134.

[5] Zhao Xiuhua. Discussion on the Application of Multi-dimensional Interactive Teaching Model in College English Teaching [J]. Modernization of education ,2020,7(2):186-187.

[6] Gu Jianfeng. Application of Multi-dimensional Interactive Teaching Model in College English Teaching [J].].1 Journal of Kaifeng Institute of Education. 